\title{
Pemeriksaan kesehatan dan komunikasi, informasi dan edukasi pada masyarakat di Galesong Utara, Kabupaten Takalar
}

\author{
Ira Widya Sari ${ }^{*}{ }^{*}$, Desi Reski Fajar ${ }^{1}$ \\ ${ }^{1}$ Farmasi, Institut Ilmu Kesehatan Pelamonia, Makassar, Indonesia
}

DOI: https://doi.org/10.29303/indra.v2i1.35

\section{Article Info}

Received : 27-07-2020

Revised : 28-04-2021

Accepted: 29-04-2021

\begin{abstract}
In the context of strengthening health development that prioritizes promotivepreventive efforts, without overruling curative-rehabilitative efforts by involving all components of the nation in promoting a healthy paradigm. IEC reduces disease expenditure, avoids a decrease in population expenditure, and decreases health care costs due to disease expenditure and health expenditure. This IEC activity is an effort to improve public health in North Galesong District, Takalar Regency, went well and was enthusiastically welcomed by the community, the purpose of this activity was to increase public knowledge about health information relating to the illness suffered. The dedication activity was attended by 45 participants, from the community service activities, it can be concluded that the community has begun to understand and comprehend and further increase knowledge about health information concerning the illness suffered. And the community is able to control health well in order to achieve improved health.
\end{abstract}

Keywords: health check, IEC, community

Citation: $\quad$ Sari, I. W. \& Fajar, D. R. (2021). Pemeriksaan kesehatan dan komunikasi, informasi dan edukasi pada masyarakat di Galesong Utara, Kabupaten Takalar. INDRA: Jurnal Pengabdian kepada Masyarakat, 2(1), 27-29. doi: https://doi.org/10.29303/indra.v2i1.35

\section{Pendahuluan}

Program Indonesia Sehat dengan pendekatan keluarga merupakan program yang diselenggarakan oleh Kementerian Kesehatan Republik Indonesia untuk mewujudkan masyarakat Indonesia yang berperilaku sehat, serta sadar akan pentingnya kesehatan (Sekretaris Kabinet Republik Indonesia, 2017). Dalam rangka penguatan pembangunan kesehatan yang mengedepankan upaya promotifpreventif, tanpa mengesampingkan upaya kuratifrehabilitatif dengan melibatkan seluruh komponen bangsa dalam memasyarakatkan paradigma sehat. Komunikasi Informasi dan Edukasi (KIE) bertujuan menurunkan beban penyakit, menghindarkan terjadinya penurunan produktivitas penduduk, dan menurunkan beban pembiayaan pelayanan kesehatan karena meningkatnya penyakit dan pengeluaran Kesehatan (Rokhmayanti et al., 2020).

Tingginya angka kejadian hipertensi menjadi di salah satu permasalahan kesehatan serius yang di Indonesia. Di Indonesia jumlah penderita hipertensi mencapai 70 juta orang. Prevalensi hipertensi pada orang dewasa di Indonesia adalah 6-15 \% (Rokom, 2019). Menurut Riset Kesehatan Data tahun 2018 prevalensi hipertensi di Indonesia penduduk usia $\geq 18$ tahun di Sulawesi Selatan sebesar 31,68\%. Angka mortalitas mencapai 18,6\% (Kementerian Kesehatan Republik Indonesia, 2019).

Galesong Utara merupakan salah satu kecamatan di Kabupaten Takalar, Provinsi Sulawesi Selatan. Luas daerah tersebut tercatat sebesar $15,11 \mathrm{~km}^{2}$. Jumlah penduduk di kecamatan Galesong Utara pada tahun 
2020 tercatat sebanyak 39.311 jiwa dengan kepadatan penduduk (jiwa $/ \mathrm{km}^{2}$ ). Jumlah penduduk laki-laki sebanyak 19.346 dan perempuan sebanyak 19.850. Mata pencaharian utama penduduk di Galesong Utara adalah nelayan. Mata pencaharian di Galesong Utara didukung dengan kondisi geografi wilayah yang daerah pesisir pantai (Badan Pusat Statistik Kabupaten Takalar, 2020).

Menurut data Dinas Kesehatan Kabupaten, masalah kesehatan yang paling banyak terjadi di Galesong Utara yakni hipertensi. Beberapa ditengarai menderita hipertensi bahkan dengan beberapa komplikasi. Mengingat angka kejadian hipertensi yang terus meningkat dan bahaya komplikasi yang ditimbulkan, maka perlu dilakukan edukasi tentang penyakit hipertensi serta pemeriksaan tekanan darah agar warga di Galesong Utara dapat memantau kondisi kesehatannya dengan lebih mudah.

\section{Metode}

Metode pengabdian masyarakat di Kecamatan Galesong Utara, Kabupaten Takalar, yang digunakan untuk menyelesaikan permasalahan mitra adalah dengan persiapan kegiatan. Persiapan kegiatan pengabdian masyarakat meliputi perijinan ke instansi terkait, penyiapan bahan/materi edukasi. Materi edukasi yang dipaparkan dalam bentuk power point.

Tahapan kedua yakni pelaksanaan kegiatan dengan pertama-tama sambutan oleh ketua pengabdian kemudian resmi dibuka oleh camat setempat. Kegiatan dilanjutkan dengan pemberian materi terkait hipertensi. Materi yang diberikan definisi, penyebab dan gejala hipertensi, bahaya hipertensi, usaha intervensi untuk pencegahan kejadian hipertensi dan tanaman herbal untuk pengobatan hipertensi.

Tahapan terakhir yakni pemeriksaan tekanan darah. Pemeriksaan tekanan darah dibantu dengan tenaga medis lainnya.

\section{Hasil dan Pembahasan}

Kegiatan pengabdian masyarakat ini telah dilaksanakan pada bulan Agustus tahun 2018 di Galesong Utara, Kabupaten Takalar. Kegiatan pengabdian dihadiri oleh 45 orang peserta yang diundang berdasarkan arahan pamong setempat.

Kegiatan pengabdian masyarakat diawali dengan melakukan KIE terkait penyakit hipertensi. Penyuluhan diberikan dengan menggunakan power point. Bahasan KIE yang diberikan yakni definisi hipertensi, penyebab dan gejala hipertensi, bahaya hipertensi dan usaha intervensi untuk mencegah kejadian hipertensi. Sebagaimana diketahui, seseorang didiagnosis memiliki hipertensi jika tekanan darah diatas 140/90 pada pemeriksaan di dua hari yang berbeda (World Health Organization, 2019). Dampak dari penyakit hipertensi yakni gagal ginjal, stroke, infark miokard, gagal jantung, kebutaan hingga kematian (Dinata, Safrita, \& Sastri, 2012). Upaya pencegahan yang dapat dilakukan adalah mengurangi asupan garam (kurang dari 5 gram per hari), mengkonsumsi buah dan sayur tiap hari, menghindari makanan yang mengandung lemak jenuh dan lemak trans, hindari rokok, mengurangi alkohol dan berolahraga secara teratur. (Hermina \& Prihatini, 2016) (Carey, Muntner, Bosworth, \& Whelton 2018). Materi seputar tanaman herbal untuk hipertensi juga diberikan. Tanaman yang dapat dijadikan obat hipertensi adalah mengkudu (Morinda citrifolia) (Sari, 2015), daun salam (Eugenia polyantha), kunyit (Curcuma longa), ketumbar (Coriandrum sativum), jeruk sitrun (Citrus limon) (Santoso, \& Suharjo, 2003).

Kegiatan pengabdian berjalan dengan lancar. Peserta pengabdian terlihat antusias dengan memberikan beberapa pertanyaan seputar hipertensi. Beberapa pertanyaan yang diberikan yakni apakah obat dari dokter (sintetik) dapat dikonsumsi bersamaan dengan jamu (obat herbal) dan apakah aman mengkonsumsi daun salam.

Diakhir pengabdian panitia pengabdian dari STIKES Pelamonia Program Studi DIII Farmasi memberikan bingkisan kepada peserta yang aktif selama sesi pengabdian. Program pengabdian diakhiri dengan foto bersama peserta pengabdian.

Dengan adanya program pengabdian dari STIKES Pelamonia Program Studi DIII Farmasi terkait edukasi terkait hipertensi diharapkan masyarakat warga Galesong Utara dapat meningkatkan kesadaran untuk melakukan pencegahan dan menerapkan pola hidup sehat guna mencegah penyakit hipertensi.

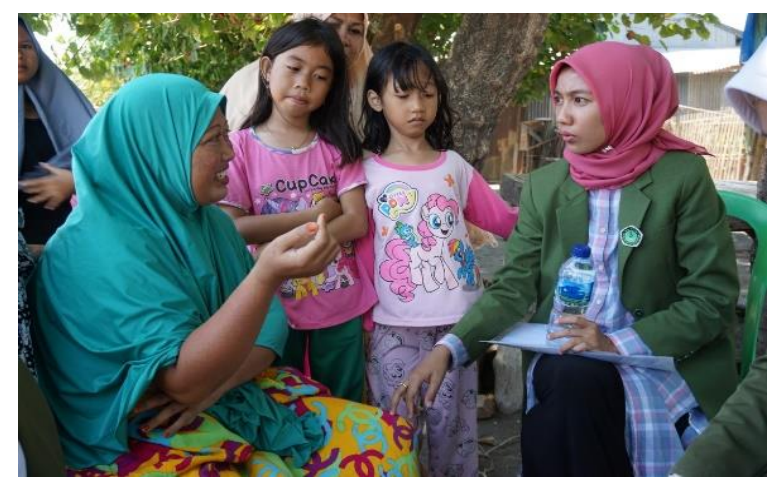

Gambar 1. KIE kepada masyarakat 


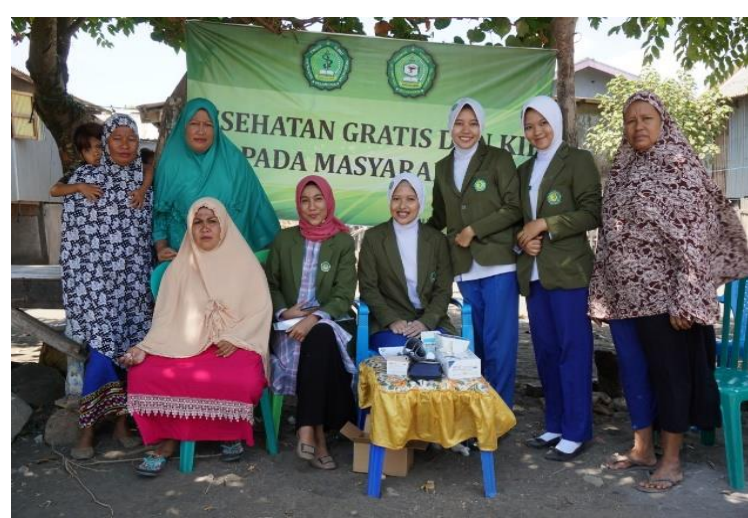

Gambar 2. Foto bersama masyarakat

\section{Simpulan}

Dari kegiatan pengabdian yang dilakukan dapat disimpulkan bahwa masyarakat Kecamatan Galesong Utara memiliki semangat dan kemauan terhadap pengetahuan terkait kesehatan hipertensi, serta diharapkan masyarakat mulai mengerti dan memahami terkait penyakit hipertensi tersebut.

\section{Ucapan Terima Kasih}

Penulis mengucapkan terima kasih kepada semua pihak yang telah terlibat dalam kegiatan pengabdian kepada masyarakat ini. Terutama kepada Prodi DIII Farmasi STIKES Pelamonia Makassar sehingga penulis dapat melaksanakan pengabdian masyarakat ini di Galesong Utara, Kabupaten Takalar.

\section{Daftar Pustaka}

Badan Pusat Statistik Kabupaten Takalar. (2020). Kecamatan Galesong Utara dalam angka 2020. Retrivied from https://takalarkab.bps.go.id/publication/2020/09/ 28/8092de911fef62c305958131/kecamatan-galesongutara-dalam-angka-2020.html

Carey, R. M., Muntner, P., Bosworth, H. B., \& Whelton, P. K. (2018). Prevention and control of hypertension: JACC Health Promotion Series. Journal of the American College of Cardiology, 72(11), 1278-1293. https://doi.org/10.1016/j.jacc.2018.07.008

Dinata, C. A., Safrita, Y., \& Sastri, S. (2012). Gambaran faktor risiko dan tipe stroke pada pasien rawat inap di bagian penyakit dalam RSUD Kabupaten Solok Selatan periode 1 Januari 2010-31 Juni 2012. Jurnal Kesehatan Andalas, 2(2), 57-61.

Hermina \& Prihatini, S. (2016). Fruits and vegetables consumption of Indonesian population in the context of balanced nutrition: a further analysis of individual food consumption survey (SKMl) 2014. Buletin Penelitian Kesehatan, 44(3), 205-218.
Kementerian Kesehatan Republik Indonesia. (2019). Laporan Provinsi Sulawesi Selatan RISKESDAS 2018. Retrivied from http:/ / ejournal2.litbang.kemkes.go.id/index.php/1 $\mathrm{pb} /$ article/view/3658

Rokhmayanti, R., Andani, R., Sunia, T.A.P., Rizka, J., Nursyavidha, N., Nurmalasari, \& N., Ishma, Z. (2020). Komunikasi, informasi, dan edukasi (KIE) dalam upaya pencegahan penyakit leptospirosis dan demam berdarah dengue (DBD) di dusun Jaranan, Banguntapan, Bantul, Daerah Istimewa Yogyakarta. Jurnal Pemberdayaan: Publikasi Hasil Pengabdian Kepada Masyarakat. 4(1), 105-112. Retrieved fromhttp://journal2.uad.ac.id/index.php/jpmuad/ article/view/2024/pdf

Rokom. (2019). Hipertensi penyakit paling banyak diidap masyarakat. Retrieved from https://sehatnegeriku.kemkes.go.id

Santoso, S.S., \& Suharjo. (2003). Obat tradisional untuk penyakit tenakan darah tinggi dari pengobat tradisional (Battra) di DKI Jakarta, D.I Yogyakarta dan Surabaya. Media Litbang Kesehatan, 12(1), 6-12. Retrieved from http://ejournal.litbang.kemkes.go.id/index.php/M PK/article/view/1026

Sari, C.Y. (2015). Penggunaan buah mengkudu (Morinda citrifolia L.) untuk menurunkan tekanan darah. Jurnal Majority, 4(3), 34-40. Retrieved from http://juke.kedokteran.unila.ac.id/index.php/majo rity/article/view/547/548

Sekretaris Kabinet Republik Indonesia. (2017). Instruksi presiden Republik Indonesia Nomor 1 Tahun 2017 tentang Gerakan Masyarakat Hidup Sehat. Jakarta.

World Health Organization. (2019). Hypertension. Retrieved from https://www.who.int/newsroom/fact-sheets/detail/hypertension 